\title{
Africa and the Changes in Eastern Europe
}

\section{THANDIKA MKANDAWIRE}

The organisers of the conference requested me to give an 'African perspective' on the transformations in East Europe, how African researchers view these events and what implications these changes will have on the economic situation in the South. I was also to compare the processes of adjustment in East Europe with those of Africa. This is a tall order. For one, African voices are multiple and not always in unison. It may thus be presumptuous for me to claim that mine is the African voice. Second, Africa itself is undergoing dramatic transformations about which there are divergent interpretations and whose outcomes are still in the realm of the unknown. Making judgements about the implications of uncertain events on the shifting African reality is a hazardous undertaking. And so my views should be considered as those of one African and their tentative character should come as no surprise given the fluidity of the situation in Eastern and Western Europe and in Africa. It is also important to bear in mind that for much of Africa the most salient implication of changes in Eastern Europe will be transmitted through Western Europe's responses to those changes and its conceptualisation of both its moral responsibilities and geopolitical interests. Consequently, considerable attention will be devoted to processes in Western Europe. I will, however, try to convey the intellectual currents in Africa and the new mood which, while perhaps sounding rather defiant, is really a reflection of the new realism in Africa.

One of the effects of the changes in East Europe is the triumphalism of the West, especially of liberal-democratic ideology. Fukuyama's declaration of the end of history may have been premature to the extent that it precipitately announced the arrival of a liberal bliss within which all major contestations can be solved without recourse to revolutionary violence. It was however a neat summation of a mood that was sanctioned by the 'return' of Eastern Europe to European civilisation. This triumphalism also bred a certain impatience with those parts of the world that stood out either as the terrible reminder of European civilisation's other legacy or that seemed so steeped in their ways as to fail to see the salvation of liberalism. With respect to Africa, triumphalism put an end to any lingering guilt about Africa's plight and fanned a studied 'afro-pessimism' [Digo, 1992]. If in the 1960s and 1970s

Thandika Mkandawire, Executive Secretary, Council for the Development of Social Science Research in Africa (CODESRIA). 
it was Africa that pilloried Europe for colonialism, neo-colonialism, exploitation, underdevelopment, in the 1980s and 1990s, the tables had been turned. Europe was now on the offensive. European contrition now turned into an aggressive indictment of almost everything African, except perhaps its music and sports. Now it was Europe pointing out the African origins of a seemingly endless chain of disasters. It was Africa's mismanagement of states and the economy [World Bank, 1981], the patron-clientalism spawned by African culture [Sandbrook, 1985; Hyden, 1980], the incessant 'rent-seeking' [Bates, 1981; Gallagher, 1991] and the resilience of Africa's pre-colonial historical trajectory [Bayart, 1983] that accounted for the disaster that Africa was undergoing. Afro-pessimism was cultivated in the media $^{1}$ and the dramatic changes in East Europe and the poor coverage of the significant, albeit not perhaps historically equally portentous, changes in Africa itself made Africa the odd man out, fanned by experts' reports on how virtually every social index was moving in the wrong direction. The press satisfied Europe's appetite for horror stories from the Dark Continent and Africa itself seemed an inexhaustible and willing supplier of such fare Somalia, Liberia, South Africa, Sudan, Angola to name a few cases.

Africa's European friends - an endangered species - were trapped in a nowin situation. If they were to obtain more resources for Africa, they had to highlight the human disasters ravaging Africa. However, this had the danger of inducing 'compassion fatigue'. It was therefore necessary to counterbalance these negative images with positive ones, but this in turn might breed complacency on the part of the European public. Another tack was to emphasise the dangers to Europe of Africa's continued underdevelopment drug trafficking, illegal migration or environmental degradation with global implications. Persuasive though this appeal to self-interest may be, it is definitely not flattering to us to realise that the only leverage we have on the global system is our capacity as a 'nuisance factor'.

\section{THE END OF THE COLD WAR}

One of the important outcomes of the changes in Eastern Europe was the end of the cold war which could not have come at a more propitious time for Africa. The last armed struggles in Africa had been fought or were about to end. Whatever the fate of the Soviet Union in human history, it did provide support that was vital in inflicting some of the most decisive defeats on colonial and racial rule in Africa. It also had the effect of diluting the racism that so easily coloured nationalism by indicating that there could be other more serious divisions among nations than that of race. The cold war had, of course, negative effects. It tied down vast amounts of human and material 
resources that could have been harnessed for nobler purposes than mutual annihilation. It made some battles bloodier than they should otherwise have been by introducing lethal weapons into local conflicts. It also tended to prolong conflicts because their resolution was not only related to local imperatives but to global parameters over which the Africans themselves had no control. This said, it still remains true that the cold war provided the African nationalist movements with valuable opportunities in their struggle for independence.

\section{DEMOCRATISATION IN AFRICA}

The African continent is witnessing processes of political change which are reminiscent in their scope and intensity of the struggle for 'collective rights' in the 1950s and 1960s. The struggle this time is for human rights and democratic governance.

Changes in Eastern Europe, especially the moves towards democratisation, have had an impact on Africa's own intellectual debates. First, in the 'Afro-Marxist' regimes, transformations in the very 'Mecca of Communism' completely undermined any pretensions to place one-party rule on a scientific basis. It is interesting that the most serious attempts so far at democratisation in Africa have been in 'leftist' regimes - Congo, Cape Verde, Zambia, Angola, etc. The 'rightist' regimes have thus far effectively resisted democratic transformation. To the extent that Africa had its own Ceauşescus, the widely-televised images of the fall of that dictator cannot have escaped the attention of an Africa that was itself in the thrall of struggle and they may indeed have inspired democratic forces in Africa. ${ }^{2}$

The end of the cold war has also devalued the geopolitical currency with which a number of authoritarian regimes in Africa purchased support from Western Europe. To the extent that the support of a number of these dictators was the outcome of the geopolitical considerations of the cold war, one can hope that changes in Eastern Europe will make the Western powers change their positions towards their past allies and make them less jittery about processes of democratisation in Africa. 'Political conditionality' imposed by the West has already pushed some dictators towards democratic solutions. One should also mention here the role of human rights and the solidarity movements of Europe and North America which have provided support to various actors in civil society. However, the fundamentals of democratisation in Africa are essentially African. Indeed, most pro-democracy movements predate the East Europeans by decades. These struggles for democracy reflect the fundamental social changes that have taken place in Africa. The African population, largely illiterate after decades of colonial 
rule, has undergone near revolutionary transformation since independence. Africa's urban centres are now more than colonial military garrisons of occupation and constitute centres of vibrant cultural and political expression. More than two-thirds of Africa's current population was born after independence and is less enamoured of ceaseless reminders about the glorious days of the anti-imperialist struggle by people who are out of touch with the lives of their own people and have lost legitimacy among a population more interested in the present and future than an increasingly mystified past. Gross mismanagement of Africa's material potential was enough to provoke the kind of response we are witnessing today in Africa.

As we noted earlier, some external pressures have played an important role. However, although the new democratic movements have welcomed the solidary actions from Europe - including the 'political conditionality' spawned by such solidarity - many of these movements remain quite suspicious of European intentions and commitment to democratisation processes in Africa. This is particularly true of the intentions of the erstwhile colonial masters who in the past have nurtured, condoned or legitimised a colourful spectrum of African dictators. The apparent sudden upsurge of 'political conditionality' may have been linked to changes taking place in Eastern Europe. However, it is also true that in the case of client African states, 'political conditionality' was aimed at forcing these states to change or perish. It was thus a way by which major powers could regain their political initiative and influence changes in a manner that was manageable. The hope was that democratic elections would be held and the incumbent would win. And after making considerable noise about how democratisation would be central to their policies in Africa, some of the major powers are retreating from these positions as concerns with their specific interests and often rather parochial economic considerations assert themselves. Even the versions of democracy they favour are peculiar ones. In many cases, donors are insisting that the new governments should be ones of 'national unity', and arm-twisting by foreign powers has forced the victorious parties to include the opposition in the government if aid is to continue. The argument by donors is that only such national coalitions can ensure stability which is putatively the sine qua non for attracting much needed foreign capital. This 'tropicalised democracy' then builds not on the effective management of pluralism but on its obliteration.

There are enormous problems faced by the democracy movements in Africa. Debilitating poverty, ill-health and illiteracy all make effective 
participation in the democratic struggles particularly difficult. If one adds to these the fissiparous tribalism and the resistance of authoritarian regimes, one appreciates how prodigious a task the democratic forces in Africa have before them. Complicating matters enormously are the external pressures on African economies to repay debts. Reconciling democratisation and structural adjustment programmes remains a major question.

Journalistic accounts and even academic treatises provide ideational explanations that suggest that a major impetus to African economic reform is the economic liberalisation in the erstwhile planned economies. 'Afrostroika', it is said, is derivative from 'Perestroika'. Strictly speaking this is not correct for much of Africa. African economies had been undergoing 'structural adjustment' of the neo-liberal type long before 'perestroika' and the transformations in Eastern Europe. What changes in Eastern Europe may have done are to make these strategies appear as the only alternative. If state interventionism has been discredited in the very heart of central planning, who were the Africans to insist on a key role for the state in the process of development? Any doubts Africans held about the efficacy of the profusely proffered neo-liberal strategies of recovery have only elicited weary observations about Africa's inability to keep up with the changing times, and dire warnings that if Africa insisted on pursuing its old ways it would only have itself to blame for its marginalisation and deepening underdevelopment.

In a broad sense both Eastern Europe and Africa are undergoing processes of political democratisation and economic liberalisation. Here similarities end. While it seems that in Eastern Europe key social movements or elements of civil society have generally embraced the dual processes, in Africa there are strong reservations about the processes of economic liberalisation. This is not surprising. While the impetus to political reforms in Africa has been largely domestic, that for economic liberalisation has been largely external. It has not been linked to profound ideological shifts within Africa itself but rather to the unrelenting exigencies of international financial institutions for debt repayment. There has thus far been no consensus about such key issues as privatisation and the general retreat of the state from a number of sectors, including the social. In Africa the grounds for nationalisation were largely nationalist and developmental rather than class specific. The result is that privatisation is judged against the logic of nationalism and development. Consequently, to the extent that privatisation means foreign control and to the extent that it has so far been associated with the general collapse of investment in Africa, there is very little enthusiasm for it in Africa.

In addition, the point of departure for structural adjustment programmes was entirely different. Eastern Europe countries were generally developed, 
centrally planned economies. In contrast, African economies were extremely underdeveloped capitalist market economies, pretensions of idiosyncratic socialism and high levels of state ownership notwithstanding. Consequently, adjustment has meant less institutional dislocation in Africa than in those cases where changes undermined the core or organisational principle of collective ownership and central planning. The market seems to have been able to impose its own logic faster in Africa than in Eastern Europe where the collapse of state structures has tended to open the door to organised crime rather than to the much vaunted 'market forces'. In addition, low levels of development in Africa have tended to make the case for state intervention on developmental grounds still attractive, thereby explaining the rather low support by African intellectuals of World Bank imposed adjustment programmes. I must add, however, that one salutary effect of the crisis is the widespread recognition of the market as an effective algorithm for a decentralised system of resource allocation. Consequently, state-market discourse has assumed a much less Manichean dichotomisation in Africa than in Eastern Europe.

\section{MARGINALISATION OF AFRICA}

Africans are often reminded that global transformations are 'marginalising' the continent. This marginalisation can take two forms. One could be through the erasure from the minds of the rest of the world of the African continent as greater attention is paid to the problems of Eastern Europe and the Asian-Pacific and North American challenges. Indeed only a few years ago, The Economist blithely observed that were Africa to somehow disappear from this earth hardly anybody would notice. Another and more palpable form of marginalisation is economic. This is suggested by such measures as Africa's share in world trade and flows of capital. Africa's share of world trade has declined from nine per cent in the 1960s to one per cent in the 1990s. The total flow of direct investment to Africa south of the Sahara was less than what went to Papua New Guinea in 1991 [United Nations, 1991]. The trends predate the reintegration of Eastern Europe into the world capitalist system. The general fear is that changes in Eastern Europe will mean that aid and investment will move away from Africa. In addition the status that Africa may have enjoyed as a mineral reserve for western economies has been undermined by Russia's return to the western fold and its vast mineral resources, its proximity to industrial Europe and the relatively high level of development of both its physical infrastructure and human resources. The hidden message was that Africa ought to be grateful for whatever relationship the rest of the world chooses to maintain with it and that Africa ought to change its investment climate or else. 


\section{THE ASYMMETRY}

So much has been said about asymmetry that one hesitates to harp on it at this point in time. And at this particular moment when Africa seems dangerously perched on the brink of marginalisation, it may seem a trifle petty to remind the world that the Africa-Europe nexus has been uneven. After all, no opportunity is missed to remind the Africans that with the odds against them they should count their blessings and simply make the best of what is admittedly an unfair relationship. I will, however, venture to restate some of these facts.

First, on the political level one is still struck by the extent of European interference in African affairs. Foreign governments continue to seek to influence the composition of governments, their policies and so on. The 'informal governance' of African countries by foreign powers still remains an outstanding feature of African political economies. It has been intensified by the African economic crisis and the continent's recourse to outside help.

Second is the fact that the relationship between Africa and Europe is such that no matter how well intentioned an act, it is almost invariably bound to turn sour. This is largely due to the fact that the framework within which such relations are embedded has the capacity to pervert virtually everything. Take the case of the EC-ACP relationship. It was supposed to stabilise the export earnings from Africa's traditional exports without ever questioning the structure of exports and the division of labour that had historically assigned Africa the role of producing the raw materials that were included in the stabilisation schemes. The effect-intended or not - was to give Africans a false sense of security that they could somehow. continue with their monocultural exports and did not need to diversify into 'non-traditional exports'. The upshot of all this was lack of diversification. Incredibly, as a result of this, sub-Saharan Africa is the only part of the world that is not likely to benefit immediately from the Uruguay GATT reforms. And so even the ending of as costly an ideological stand-off as the cold war threatens Africa's interests.

Third is the puzzle that, close to each other as Africa and Europe are culturally, politically and geographically, the relationship has not been conducive to the development of the former. In the 1960s a widely acclaimed textbook on development suggested that Africa had fewer cultural barriers to development than Asia because it was not encumbered with such inscrutable cultural excess baggage as Confucianism and other various forms of Asiatic mysticism. Africa was open to western culture in a way that Asia and the Orient was not. Its elites were trained in the best institutions and had mastered European languages to an extent that was rare in the Far East. 
This 'openness' to Europe would make 'modernisation' (read Europeanisation) a much easier process in Africa than in the inscrutable orient. As it turned out Africa's openness to Europe and the peepholes through which the continent was to visualise Europe proved fatal. First, it nourished a mimetic culture that sapped Africa's creativity, especially among the first generation of the African leadership. Second, among Europeans, the openness led to a blasé familiarity with Africa, encouraging a phenomenon of 'instant expertise' on all African matters that was unimaginable in other parts of the world. It was almost enough to love Africa to know it. Third, the apparent malleability of Africa proved a great temptation to those with strong inclinations towards social engineering. And so, behind a tantalising number of wacky schemes in Africa, there was always a band of Europeans (and later Americans) providing the intellectual rationale for state policies. Africa's own 'colonial mentality' opened the ears of the leadership to all kinds of mad ideas, making Africa such an attractive place for advisers, quacks and fortune seekers. The Africans' reverence for foreign expertise only fanned the hubris of the experts.

We should not forget that the 'colonial mentality' that Fanon so clinically and meticulously diagnosed did not only afflict the victims but also the tormentors. For how else does one explain not only the almost mystical reverence in which European expertise was held but also the actual acceptance by the Europeans of their godlike role. How is one to account for the fact that during the last decade we have witnessed the return of Europeans in all guises, reversing a trend of indigenisation initiated after independence? Today 4,000 Europeans hold key technical positions and cost an estimated six to seven thousand million dollars. Not since colonial days has Africa been under such intensive foreign tutelage as at present. The number of experts from Europe is simply tantalising and yet at no time has Africa been endowed with so many skilled autochthons as today. This highly qualified and under-utilised young generation resents foreign tutelage or at least is not convinced of the necessity for the hordes of peripatetic experts that hop from one country to another. Although they understand the concern for Africa's economic manaagment by those to whom Africa owes money, especially as it affects debt servicing, they resent the inference that the moneylenders should run their countries. They are also not quite convinced of the morality of repaying debts incurred by dictators who have stashed the money away in European banks.

One need not subscribe to the theory of delinking to suspect that the loosening of ties between Europe and Africa may have a salutary effect. It is hard not to believe that this large presence of experts - for this is what they are called regardless of their skills - is one of the contributory factors to the African malaise. A senior World Bank official has been compelled to admit 
as much. If these hordes of European experts were to be somehow shifted elsewhere, I do not believe Africa would be the worse for it, at least not in the long run. The current form of integration of Africa into the world system leaves much to be desired and much of the debate on Africa's marginalisation fails to problematise this integration. Current African-European relationships are asymmetrical and have permitted levels of intervention by Europe that continue to humiliate Africa and violate the most elementary claims to sovereignty and blunt its own initiative.

\section{NEW WORLD ORDER}

The triumph of the West has also raised the prospects of a New World Order. This has nothing to do with the now inaudible calls for a new international economic order. Rather it is a call for the edification of an order in which one military superpower will, in collaboration with other economic superpowers, lord it over the rest of humanity. It is an order in which once again asymmetry will be the keystone. As an African, I am keenly aware that as the weakest continent we are bound to bear the brunt of this order. One of Africa's new worries is the doctrine of humanitarian interventions in cases where state structures endanger the lives of the citizenry. Africa's worry is that the principle is likely to be applied asymmetrically and discriminatingly. Europe's readiness to intervene in Somalia and its impotence and ambivalence over Bosnia has left Africans quite puzzled about the universality of the new doctrine. It is hard for Africans to believe that the plight of Somalia has touched the heart of Europe more deeply than that of Bosnia. Even with respect to the political conditionality that such an order will putatively insist on, it is only in Africa, with its extreme desperation and the enormous financial leverage which donors have in our economies, that the UN and Bretton Woods Institution have insisted on respect for human rights as a precondition for financial assistance. We will watch closely the political performance of the European Bank of Development and Reconstruction which is statutorily bound to link its aid to democratisation.

\section{GROWING RACISM}

The end of the cold war has also unleashed those terrible primordial forces that Europeans had generally assigned to others - 'tribalism', ethnic conflict, territorial expansionism and so on. Twice this century, European rages have engulfed the world in extremely destructive world wars. Africans are concerned by these forces and the peculiarly European solutions to such problems, for example, ethnic cleansing and wars. For historical reasons 
Africans are most stirred by the racist dimension of these forces and are quite bewildered by the violent turn that ethnicity has taken and the implications of such things as ethnic cleansing. If European history is anything to go by, Africans and their descendants will be the most visible victims of this racism. We are therefore deeply concerned.

\section{CONCLUDING REMARKS}

Let me end my remarks on a more optimistic note if only because Afropessimism that is raging in Europe is not one of the many afflictions ravaging Africa. ${ }^{3}$ It is symptomatic of what is wrong with Africa's position in the world that democratisation and economic recovery in Eastern Europe should be considered threats to Africa's well-being. To the extent that changes in Eastern Europe signal the end of imperial domination and the beginning of a new society based on respect for human rights, Africa can only benefit from such a change. Africa should also see the recovery of Eastern Europe as creating potential markets for its products. For as much as aid is touted, Africa's principal source of foreign goods, technology and services, is financed by its exports.

We would very much like to have first-hand knowledge of what is going on in Eastern Europe. Contacts between East European and African researchers were always conditioned by larger inter-state considerations. In the past, access by Africans to what was going on in Eastern European research was mostly confined to officially sanctioned translations of works by East European Africanists. Much of this work was marred by the apologetic tasks to which it was rather crudely harnessed. Currently, our knowledge of what is going on in Eastern Europe is non-existent or is largely filtered through the distorting prism of a western media which has tended to be more celebrative of the triumph of liberalism than analytical. Africa must forge new links with East Europe. One possible initiative would be to organise more encounters between Eastern European and African intellectuals. We might learn something from the experiences with economic transformation and political liberalisation. How is Eastern Europe handling the 'national question', religious fundamentalism and tribalism? What opportunity does their opening up offer to Africa? They may, in turn, learn from us, for instance, on how to manage multi-ethnic nation-states.

The dramatic changes have also had the salutary effect of destroying a number of myths and awakened Africa to the real challenges it must face. And in many ways Africans are taking up the challenge. During much of the cold war, Africa worked under the numbing illusion that there were other countervailing powers that served to dilute Europe's overbearing presence in Africa. African diplomats prided themselves on exploiting these conflicts. 
But as ancient African wisdom should have reminded them, when two elephants fought it was the grass that suffered. And one might add that the fate of the grass was the same even when the embrace between elephants was amorous. One aspect of the 'marginalisation' debate relates to aid. If there was any lingering hope about a 'Marshall Plan', induced by the West's fear of 'losing Africa', that hope is now dead and buried. All indicators are that aid to Africa will decline and this for a number of reasons. First, there is the 'aid fatigue' following what is increasingly seen as the ineffectiveness of aid, at least in the form it takes in Africa. Second, the demands of Eastern Europe appeal more directly to western interests and tribal instincts. The fear of wars, including between nuclear-armed states, and the danger of tribal conflicts in Europe suggest that it would be prudent of Europe to help the neighbour whose house is burning and whose security matters more than responding to the moral claims of some distant and probably fraudulent relative. Africa is thus best advised increasingly to seek internal resources for development or to earn them in a highly competitive world. Indeed, Africa is turning inwards in both its intellectual and political foci with a view to reshaping the conditions of its integration into the world system.

In conclusion, much is happening in Africa that will enable the continent to live and even gain from some of the positive changes in Eastern Europe. And much of this is quite visible if one pays careful attention to the voices of Africa. At no time before have so many books and so many newspapers been published by Africans as today. These debates are engaged, wellinformed, brutally frank and in many ways signal the end of a colonial mentality that either pushed us into self-defensive positions or shameful subservience. The issues covered include democratisation, regional cooperation, culture and so on. Africa is a continent of the young. More than two-thirds of the African population was born after African independence and is therefore not marked by the scars of domination that induced a 'colonial mentality' in the early leaders of Africa. The opening of political space has revived political debates and ushered new young voices onto the political scene. This is bound to affect Africa's future profoundly.

It is true and obvious that Africa faces many challenges but there are few, if any, that it cannot eventually deal with. What Africa asks for from the rest of the world is less interference and more respect for the sovereign rights of its peoples. It asks for solidarity that supports Africa's own efforts. I am personally persuaded that morality and human decency both demand that where the rest of the world can, it should support Africa's efforts at democratisation and elimination of the scourges of hunger, ignorance and disease that still afflict much of Africa. I am also convinced that Africa has to learn to live with a world where other nations' interests may divert attention to areas that are not of immediate interest to Africa. 


\section{NOTES}

1. The French Press was not to be outdone in this orgy of Afro-pessimism. See Le Point, No.926, 6 April 1990; Le Nouvel Observateur, 6 June 1990; Cahier de l'Express, No. 6, 20 Nov. 1990, with the telling title 'Africa: The Tragedy: The Political Failure, Economic Ruin, Ethnic Conflicts, the Game Powers, Aids, Famine, Refugees'.

2. Former Nigerian President, General Obasanjo, has noted: The 'Ceauşescu factor' was the single most important event that led to a rapid re-orientation by many African leaders with a view to adopting political and economic reform programmes aimed, in varying degrees, at introducing accountability of political leaders and institutions, a multi-party system, participatory democracy and accessibility, rule of law, and observance of human rights. Cited in Zdenek [1993].

3. To be sure, some Africans have been infected by the malaise. See, for example, Ka Mama [1990].

\section{REFERNCES}

Bates, R., 1981, Markets and States in Tropical Africa (Berkeley and Los Angeles, CA: University of California Press).

Bayart, Jean-François, 1993, The State in Africa: The Politics of the Belly (London: Longman).

Deng, L., Kostner, M. and C. Young (eds.), 1991, Democratisation and Structural Adjustment in Africa in the 1990s (Africa Studies Program; University of Wisconsin-Madison).

Digo, D., 1992, 'Is there Hope for Sub-Saharan Africa?', Contention: Debates in Society, Culture and Science, Vol.1, No.3.

Gallagher, Mark, 1991, Rent-Seeking and Economic Growth in Africa (Boulder, CO and Oxford: Westview Press).

Hyden, G., 1980, Beyond Ujama in Tanzania: Underdevelopment and an Uncaptured Peasantry (Berkeley, CA: University of California Press).

Ka Mama, 1990, L'Afrique: va-t-elle Mourir? (Paris: Cerf).

Sandbrook, R., 1985, The Politics of Africa's Economic Stagnation (London: Macmillan).

United Nations, 1991, World Investment Report: The Triad in Foreign Direct Investment (New York: United Nations).

World Bank, 1981, Accelerated Development for Africa: An Agenda for Action (Washington, DC: World Bank).

Zdenek, Cervenka, 1993, 'The Impact on Africa of the Changes in Eastern Europe and of the Gulf War', in M. Von Troil (ed.), Changing Paradigms in Development-South, East and West (Uppsala: The Scandinavian Institute of African Studies). 